\title{
Plant insulin or glucokinin: a conflicting issue*
}

\author{
José Xavier-Filho1*, Antônia Elenir A. Oliveira ${ }^{1}$, Luciana Belarmindo da Silva ${ }^{1}$, Cassiana Rocha Azevedo ${ }^{1}$, \\ Thiago Motta Venâncio${ }^{1}$, Olga Lima T. Machado', Maria Luiza Oliva ${ }^{2}$, Kátia Valevski S. Fernandes ${ }^{1}$ and $^{1}$ \\ José Xavier-Neto ${ }^{3}$
}

\begin{abstract}
${ }^{1}$ Laboratório de Química e Função de Proteínas e Peptídeos, Centro de Biociências e Biotecnologia, Universidade Estadual do Norte Fluminense, Av. Alberto Lamego 2000, 28013-600, Campos dos Goytacazes, RJ, Brazil; ${ }^{2}$ Departamento de Bioquímica, Universidade Federal de São Paulo, Escola Paulista de Medicina, Rua Três de Maio 100, 04044-020, São Paulo, SP, Brazil; ${ }^{3}$ Laboratório de Genética e Cardiologia Molecular, Instituto do Coração, Hospital das Clínicas, Faculdade de Medicina, Universidade de São Paulo, Av. Dr. Enéas C. Aguiar 44,05403-001, São Paulo,SP, Brazil.*Corresponding author:xavier@uenf.br
\end{abstract}

Received: 12/06/2003, Accepted: 23/06/2003

The presence of insulin in plants is not accepted by the scientific community in general. In this review we discuss this paradigm and retrieve information that strongly suggests that insulin is indeed found in plants. We present results, which indicate that a protein molecule with the same amino acid sequence as bovine insulin is expressed in leguminous plants. Additionally, we provide evidence that proteins associated with insulin signalling pathways in vertebrates are also found in association with insulin-like molecules in plants.

Key words: insulin, glucokinin, peptide hormone, plants, amino acid sequence, evolution.

Insulina de plantas ou glucocinina, um assunto conflitante: A presença de insulina em plantas não é aceita pela comunidade científica em geral. Nesta revisão, discutimos esse paradigma e recuperamos informações que sugerem fortemente a presença de insulina em plantas. Adicionalmente, apresentamos resultados obtidos por nós revelando a presença em leguminosas de uma proteína com a mesma seqüência de aminoácidos da insulina bovina. Apresentamos, também, evidências da presença em plantas de proteínas normalmente associadas à sinalização por insulina em vertebrados.

Palavras-chave: insulina, glucocinina, hormônio peptídico, plantas, seqüência de aminoácidos, evolução.

\section{INTRODUCTION}

The presence of the protein hormone insulin in plants is not accepted by the Plant Science community. This may be considered a paradigm (Kuhn, 1970). Many arguments, some of anecdotal nature, are utilized to reject the presence of insulin in plants. The strongest one, which is supported by comparative genomics, is that the presence of insulin in plants would contradict the generally accepted view that insulin evolved only in the metazoan lineage. Other argument is that plants do not have a need for this hormone since they do not translocate glucose but sucrose. Some say plants lack a pancreas and therefore do not produce insulin. Others state

\footnotetext{
*This work is dedicated to the memory of Socorro Xavier.
}

that, since insulin is a hormone in animals, plants would likely not have a "use" for it. In fact, there is no modern Botany, Plant Physiology or Plant Biochemistry textbook that includes the word "insulin" in its index. Nevertheless, recent and strong evidence argues for the presence of insulin in plants, suggesting that the hormone plays similar roles in plants as it does in metazoans (Assaad, 2001; Ryan et al., 2002; Jonak and Hirt, 2002).

The accepted paradigm against the presence of insulin in plants likely arose because no modern Plant Scientist has ever needed to explain glucose cellular uptake, by invoking the participation of a signalling pathway such as the insulin pathway in metazoans. Not even the comparison between plant cells and animal cells in that they both share the fundamental metabolic process of glucose utilization suggests 
that insulin may also be part of a plant signalling pathway for glucose uptake (Rolland et al., 2001). On the other hand, since the discovery of insulin, a handful of reports have appeared in the scientific literature which strongly suggest that plants produce a protein with most of the characteristics of vertebrate insulins.

The discovery of the peptide hormone insulin in the pancreas of dogs gave hope for millions of people who suffered from the highly debilitating human disease Diabetes mellitus. This condition, which in some cases develops early in childhood, is characterized by high levels of glucose in the blood due to a deficiency in insulin, which in normal subjects promote the uptake and subsequent metabolization of the sugar. With the purification and wide commercial production of insulin Diabetes mellitus is now a controllable disease. Diabetes Mellitus is known to man since time immemorial (Korczowski, 1985) and many treatments for this disease used in the antiquity were based on the utilization of plants and plant parts (Papyrus Ebers). Old World medical systems, like Ayurveda utilize plants and herbs to treat diabetes (Grover et al., 2002). Diets based on green vegetables, infusions (made using flowers or leaves in hot water), decoctions (made using the bark, seed, or root in boiling water), steeped leaves or stems, or simply water extracts have been used since long (Ajabnoor and Tilmisany, 1988). The scientific basis for the utilization of most of these so-called "natural medicines" has nowhere been elucidated but active principles have been isolated and shown to be small molecules of several chemical classes. This is the case of metformin, which was developed from biguanides present in the leaves of the legume plant Galega officinalis (Bailey and D ay, 1989) salacinol, an $\alpha-$ glucosidase inhibitor extracted from the roots of Salacia reticulata (Yoshikawa et al., 1997), and cryptolepine, an indoloquinolene alkaloid isolated from the leaves of Cryptolepis sanguinolenta (Luo et al., 1998).

These "natural medicines", based on plants and plant parts, continue to be utilized by poor populations all over the world (Gray and Flatt, 1997). As indicated above the scientific basis for their utilization is known for very few of them and the medical community mostly consider these "natural medicines" of very limited value for the treatment of the disease (Ernst, 1997).

Although it may be difficult to prove, at the moment, that these "natural medicines" have any effect on lowering blood glucose levels we suggest that in certain conditions and for specific types of plants this may be possible. Previous data indicate that insulin ingested together with protease inhibitors is protected from hydrolysis in the digestive tract, crosses the intestinal barrier and promotes lowering of blood glucose levels (Laskowski et al., 1958). Additionally, the isolation of a galactorhamnan polysaccharide in complex with insulin from the seed coats of Jack bean suggests that the hormone could be protected from hydrolysis in the digestive tract and in this way promote lowering of blood sugar after traversing the intestinal barrier (Oliveira et al., 1999a; Oliveira et al., 2001).

Since its discovery a formidable amount of research, both academic and medically oriented, has established that insulin, besides playing its role as the classical hormone associated with the catabolism of glucose, is also involved in growth, reproduction and longevity processes in metazoans (Oldham and Hafen, 2003). Many of the components of the signalling pathway in which insulin is involved have been identified although a full understanding of their roles is far from complete (Zick, 2001). Apart from its classical role in metabolic processes involving glucose, insulin has been discovered in both vertebrate and invertebrate organs and tissues. In invertebrates insulin or insulin-like hormones were shown to be synthesized in brain tissues (Smit et al., 1998). Interestingly, as insulin was not believed to be present in the brain of vertebrates until as late as 1981 (Eng and Yalow, 1981), this work in invertebrates has led to discovery of insulin synthesis in mammalian brain suggesting its wide tissue distribution (Schechter et al., 1988).

Insulin or insulin-like peptides have also been detected in the prokaryote Escherichia coli and in the unicellular eukaryote Tetrahymena (LeRoith et al., 1985) as well as fungi (Best et al., 1924; LeRoith et al., 1980; Muthukumar and Lenard, 1991; Silva et al., 2002) and a cyanobacterium (Silva et al., 2002).

In this review we recover information on the presence of insulin in plants, which has long been hidden in literature and discuss results of recent research on plant insulin, which is presently being done in a few laboratories around the world.

\section{Early work: the discovery of insulin and of glucokinin}

Pancreatic insulin was discovered in 1921-1922 after a collective effort led by Frederick Banting at the University of Toronto (Banting et al., 1922). Insulin was crystallized (Abel, 1926) before it was shown to be a protein (Wintersteiner et al., 1928; du Vigneaud et al., 1928). Soon 
after its discovery insulin was established as the universal drug for the treatment of diabetes.

Right after the discovery of insulin, J. B. Collip and C. $\mathrm{H}$. Best reported the presence of insulin-like substances in plant materials like green tops of onions, lettuce leaves, green bean leaves, barley roots, beetroots, and others. Collip was the trained biochemist that developed the method for the extraction of insulin from pancreas. In 1923 he published a paper in which he relates, after some reasoning on the properties of yeasts and plants (he states that "yeast is a plant"), that he had decided to test for the presence in plants of "a hormone similar to, if not identical with, that produced by the islet cells of the pancreas". He then utilized several extraction procedures including the one employed in the preparation of pancreas insulin. After obtaining plant extracts he performed experiments on normal rabbits and pancreatectomized dogs obtaining measurable decreases in the levels of glucose in the blood of the animals. We cite from his paper some of his appreciation of the results: "The discovery of this hormone in tissues of the higher plants as well as in yeast opens up a new field of work in plant metabolism and affords another remarkable example of parallelism in certain physiological processes in the plant and animal kingdom". In another passage he says, "As the name insulin was given by the Toronto group to an extract of pancreas prepared according to a definite method elaborated by the writer, this somewhat analogous hormone derived from plant sources must be known by a more general term. The name "glucokinin" is suggested by the writer as an appropriate term, suggestive of its metabolic activity rather than its place of origin" (Collip, 1923).

Charles Best, still a medical student at the University of Toronto, and responsible with Frederick Banting for the clinical tests on animals and humans, reported also in 1923, that insulin-like materials were present in germinating potatoes and rice. It is interesting to quote from his paper: "In November, 1922, during the course of conversation with Dr. R. T. Woodyatt (an American physician), in which the mechanism of the action of insulin was discussed, the idea presented itself that a hormone analogous to insulin might be present wherever glucose is metabolized, i.e., it might be present in plants" (Best and Scott, 1923). The following year he reported again on the presence of insulin-like materials in plants. This time he presented results on preparations from beetroot, the extracts from which exert their effects on the lowering of blood sugar as rapidly as insulin (Best, 1924).
It is highly entertaining to know that only two years after the discovery of insulin from pancreas and its approval as a new drug treatment for Diabetes mellitus, many papers, including a review paper were published by components of the Toronto group which unquestionably referred to the presence of a hormone like insulin in plants (Macleod, 1924). There was no prejudice as to whether plants would not have a need for this hormone. On the contrary, one of these papers suggests that: "In view of these results we believe that insulin may prove to be a constituent of every cell in which carbohydrate is metabolized..." (Best et al., 1924).

\section{Work with plants after the discovery of insulin}

Already in 1923 M. M. Ellis and W. H. Eyster (a maize geneticist) at the University of Missouri reported in Science, what they call qualitative results on the action of insulin and glucokinin on maize germination. The effects of solutions of either insulin or glucokinin from fresh beef pancreas and onion tops, respectively, prepared by the method developed by Collip were observed with low and high concentrations of the preparations. They refer that the higher concentrations retarded growth while the less concentrated ones were beneficial (Ellis and Eyster, 1923). In the following year these authors published what they called their quantitative results on the action of insulin and glucokinin on maize germination (Eyster and Ellis, 1924). This time they used glucokinin prepared from onion tops as well as from young maize seedlings and utilized inbred lines of maize in their experiments. They used hundreds of seedlings in seven different types of experiments to come to the same results reported in their previous note that is, both insulin and glucokinin promote the growth of maize seedlings.

No research on insulin/glucokinin from plants was done after this pioneering work of the 1920s. This was the picture until the 1970s when silence was broken when P. Khanna and collaborators reported on the presence of insulin in plants (Khanna et al., 1974) and immediately patented a process for its production from the fruits of Momordica charantia (bitter gourd) (Khanna et al., 1976). Differently from the motivation of the pioneers on glucokinin research, the background and interests of this Indian group resided in the utilization of the product for the treatment of diabetes (Welcome to Gourdin.com - Herbal Diabetes Mellitus Treatment, http:// www.gourdin.com). In any case they isolated a protein from both mature fruits and cultures of roots. The extraction was done in acidic ethanol, essentially as done by the Toronto 
group more than 50 years before (Best et al., 1924). The isolated product, which was diversely named v-insulin, polypeptide-p or p-insulin, showed hypoglycemic activity but differed in other properties from insulin. For example, it was not immunoreactive with anti-bovine insulin antibodies and its amino acid composition differed from that of animal insulin (bovine) in that it contained methionine residues (Khanna et al., 1981).

Further work on the possible presence of an insulin molecule in M. charantia was done by Ng et al. (1986). These authors utilized the seeds and employed the same acidic ethanol procedure used to extract insulin from several tissues. An elaborate scheme of purification in which they employed gel filtration and ionic exchange chromatography led to the isolation of several pure fractions which showed properties similar to animal insulins. They conclude that the seeds of $M$. charantia contain insulin-like molecules.

Following these reports, in the beginning of the 1980s, a group of endocrinologists at the Diabetes Branch (NIDDK, NIH/USA), published a series of papers in which they produced evidence for the presence of insulin in several organisms. They detected insulin-like molecules in bacteria (Escherichia coli), protozoa (Tetrahymena pyriformis), fungi (Neurospora crassa, Aspergillus fumigatus). They isolated molecules that were similar to animal insulins in several aspects like solubility, chromatographic behavior, cross-reactivity with anti-insulin antibodies and bioactivity (LeRoith et al., 1980; LeRoith et al., 1981, 1985). The results suggested to the authors "that insulin may have arisen earlier in evolution than had previously been thought" and pointed to the possibility of its presence in plants. In 1987 this group published results on the isolation of proteins from etiolated rye, leaves of spinach and Lemna giba, which showed properties similar to animal insulins. They had the same molecular masses $(6 \mathrm{kDa})$, chromatographic (gel filtration, ion-exchange, reverse phase), immunological (quantitative radio immunoassay, column immunodepletion of immunoactivity), and bioactive (stimulation of glucose incorporation to adipocytes) properties. In the discussion section of the paper the authors address the possibility of contamination with animal insulin: "All equipment used for these experiments was new and then dedicated to use only with plant material, or disposable". They go on to speculate on the presence of insulin in prokaryotes (see above) and also in the animal and plant kingdoms: “...this suggests that they are conserved, rather than the result of convergent evolution or late transfer of DNA from vertebrate sources, although we cannot exclude these possibilities". Unfortunately the authors did not perform any sequence analysis on their plant insulins and did not contributed further to the field (Collier et al., 1987).

After a long period in which no report is found in the literature of any plant physiological work related to insulin, Goodman and Davis (1993) reported that added insulin, insulin like growth factors I and II (IGF-I and IGF-II) accelerate the post-germinative development of fat-storing seeds (sunflower, watermelon and cucumber). They also measured increased activities of enzymes necessary for the conversion of fat to carbohydrate like fatty acyl CoA dehydrogenase, citrate synthase, malate dehydrogenase, isocitrate lyase, and malate synthase. No mechanism is suggested by the authors to explain this increase in enzyme activities although they hint at the possible increase in protein synthesis. The authors call attention to "the possibility that there are hormones and/or growth factors that have a regulatory role in both plants and animals" and some of these could be insulin-, and IGF-like proteins (Goodman and Davis, 1993).

Work by Barbasov et al. (1991) and Komatsu and Hirano (1991) showed that insulin and insulin-like growth factor (IGF) bind to a basic protein from soybeans and other plants. This protein was shown to have protein kinase activity suggesting that it might be a component of a signaling cascade in which insulin or a related molecule is also part. Following this suggestion Watanabe et al. (1994) isolated from soybeans a $4 \mathrm{kDa}$ peptide, which they named leginsulin. The amino acid sequence of the protein was determined and shown to have no similarity with insulin or insulin-like growth factors. Based on sequence similarities the authors suggest that this protein is also present in pea seeds. Western-blotting experiments additionally indicate its presence in adzuki and mung beans, and carrot (Watanabe et al., 1994). Additionally, Ilgoutz et al. (1997) demonstrated transcription of a leginsulin gene in developing lupin cotyledons. Although with structures differing from those of the insulin and insulin-like growth factors (IGFs) these leginsulins from legumes could well be partners in signaling pathways akin to the ones in which those hormones are involved. Recently these researchers suggested that this peptide is involved in the regulation of callus growth and cell proliferation. They also made a retraction of the name leginsulin previously given to it and now, stating that the peptide is not insulin, prefer to name it "the $4 \mathrm{kDa}$ peptide" (Yamazaki et al., 2003). 
Recently, in a follow-up paper on the effects of insulin in ribosomal protein synthesis in maize embryonic axes germination (Sánchez de Jiménez et al., 1999; Dinkova et al., 2000), which reminds us of the work by Eyster and Ellis (1924) on the effects of insulin and glucokinin on maize germination, Sanchez de Jimenez and colleagues reported on the isolation of a $20 \mathrm{kDa}$ protein from maize embryonic axes. Utilizing an affinity chromatography procedure with a bovine insulin antibody-Sepharose column they showed that this protein displays IGF (insulin-like growth factor) activity and its action is similar to that promoted by bovine insulin when applied to maize axes during germination. Furthermore, induction of the $\mathrm{S} 6$ ribosomal protein phosphorylation by the $20 \mathrm{kDa}$ protein is prevented by rapamycin and wortmannin, specific inhibitors of the insulin-stimulated phosphoinositide 3-kinase (PI3K) pathway. Unfortunately, no sequence information was given for this protein (Flores et al., 2001).

In summary, all this evidence would seem to indicate that peptide hormones whose actions are similar to the peptide hormones largely admitted to be present only in vertebrates, namely insulin and the insulin-like growth factors, are also present in plants. Some of these have been isolated and characterized, and their amino acid sequences determined and shown to differ from the animal hormones. Nevertheless others, which were not completely characterized, share many chemical and biological properties that suggest they are proper insulin molecules.

\section{New discoveries}

In this section we discuss how work done in our laboratory was influenced by our serendipitous discovery (or rediscovery) of insulin in plants. Our laboratory has mostly been directed to the elucidation of the biochemical basis of bruchid (insect) resistance shown by some legume seeds (Macedo et al., 1993; Fernandes et al., 1993; Xavier-Filho et al., 1996; Sales et al., 2000). As such, investigation of potentially toxic proteins from the seed coat of the legume Canavalia ensiformis to Callosobruchus maculatus (cowpea weevil) led Elenir Oliveira to isolate and purify a number of proteins from this material. One of these purified proteins was submitted to sequencing as an assignment for a training course. The resulting analysis showed unambiguously that the protein had the same amino acid sequence as bovine insulin (Table 1). To control for potential contamination, the analysis was repeated with different samples of the protein obtained from different batches of seeds and the amino acid sequencing analysis was also performed by two independent laboratories. After obtaining a total of seven analyses for the sequence we were convinced that the seed coat of $C$. ensiformis indeed contained a protein with a sequence equal to that of bovine insulin (Oliveira et al., 1999a). In this manuscript we suggested that molecules of insulin in seed coat tissues survive desiccation after maturation of the seed and, together with other proteins can be easily extracted. The high solubility of these proteins is certainly due to the lack of tannins and pigments in this tissue (Oliveira et al., 1999a; Oliveira et al., 1999b). These insulin molecules (and also a peptide fragment of a receptor-like-kinase accompanying the protein, see Table 2) in the seed coat seemed to be remains of constituents of signaling pathways probably involved in the transport of carbohydrate (Oliveira et al., 1999a). Contrary to our expectancies our results were received with disbelief.

Table 1. Amino acid sequences of bovine insulin and insulins isolated from Canavalia ensiformis, Vigna unguiculata and Bauhinia variegata.

\begin{tabular}{|c|c|}
\hline Plant species & Insulin sequence \\
\hline Bovine insulin $\alpha$-chain & 1 GIVEQCCASVCSLYQLENYCN 21 \\
\hline Bovine insulin $\beta$-chain & 1 FVNQHLCGSHLVEALYLVCGERGFFYTPKA 30 \\
\hline C. ensiformis I-SC & 1 GIVEQCCASVCSLYQLENYCN 21 \\
\hline C. ensiformis I-LC & 1 FVNQHLCGSHLVEALYLVCGERGFFYTPKA 30 \\
\hline V. unguiculata $\mathrm{I}-\mathrm{SC}$ & 1 GIVEQXXASVXSLYQLENYXN 21 \\
\hline V. unguiculata I-LC & 1 FVNQHLXGSHLVEALYLVXGERGFFYTPKA 30 \\
\hline B. variegata a & 1 GIVEQ 5 \\
\hline B. variegata $b$ & 1 FVNQH 5 \\
\hline
\end{tabular}

At our laboratory a new research initiative was established for the study of insulin in plants. We decided to look at the question from three different sides. First, we wanted to know where this protein is located in the seed coats of $C$. ensiformis and also what would be its behavior during germination. We also wanted to know if plants known for their supposedly antidiabetic effects would express the protein in the tissues normally employed in the treatment of the disease. And thirdly, we wanted to know how widespread this protein molecule would be in the plant kingdom. Very soon results were coming out of the laboratory.

We found by immunofluorescence microscopy analysis that insulin, insulin receptor and phosphoserine proteins are localized to an internal tissue layer of the seed coat but not in cotyledon tissues of $C$. ensiformis. This region is assumed to be important in sugar transport to the embryo. We then em- 
ployed bovine insulin to test if it has any effect on germination of $C$. ensiformis seeds. The results showed that insulin, vanadyl sulfate (an insulin mimetic compound), pinitol (a chiro inositol analogue) and glucose were able to accelerate C. ensiformis seed radicle and epicotyl development and on the contrary, tyrphostin (an inhibitor of insulin receptor kinase activity) inhibited these processes (Oliveira AEA, Ribeiro ES, da Cunha M, Gomes VM, Fernandes KVS, Xavier-Filho J - Insulin accelerates germination and development of Canavalia ensiformis (Jack bean) seeds. Submitted for publication).

C. ensiformis is an annual, semi-domesticated legume with long germination and developmental times making it a less than ideal model for germination and developmental studies. Therefore we utilized common bean (Phaseolus vulgaris) as a more convenient model plant. We showed that increasing concentrations of added bovine insulin (for $72 \mathrm{~h}$ ) promote an increase in the mass and size of radicles and epicotyls of $P$. vulgaris and also in the number of lateral roots. Additionally we extracted and purified a protein from embryonic axes $(48 \mathrm{~h})$, which cross-reacted with an antihuman insulin antibody (Santos, 2003).

The above results on the effects of added insulin in germinating seeds are clearly reminiscent of those from Eyster and Ellis (1924) on the action of insulin on maize germination and of Goodman and Davis (1993) on the effects of insulin in postgerminative development of fat-storing seeds.

We also choose a second fast growing plant, cowpea (Vigna unguiculata) to test for the presence of insulin during development. The protein was detected (by Western blotting) both in empty pods and seed coats but not in the embryo. Insulin was measured by an ELISA assay using an anti-human insulin antibody. The highest concentrations (about $0.5 \mathrm{ng} \cdot \mu \mathrm{g}^{-1}$ of protein) of this protein were found in seed coats of 16 and 18 DAP (days after pollination) in which case the values were 1.6 to 4.0 times higher than the values found for isolated pods of any day. Insulin was isolated from 10 DAP empty pods by the method of Khanna et al. (Khanna et al., 1976), purified by C4-HPLC and submitted to $\mathrm{N}$-terminal amino acid sequencing. The amino acid sequence was found to be equal to the sequence of bovine insulin and to the sequence of the insulin isolated from C. ensiformis seed coat (see above and Table 1) (Venâncio, 2001; Venâncio et al., 2003).

The leaves of many plants of the genus Bauhinia (Leguminoseae), known as "pata-de-vaca" in Brazil and cow's foot in English speaking countries, are considered to allevi- ate the symptoms of diabetes (Juliane, 1929). A great number of investigations have not as yet clarified whether this use has a scientific basis or what types of compounds are responsible for the effects (Pepato et al., 2002; da Silva and Cechinel, 2002). We choose to investigate the presence of insulin-like molecules in the leaves of Bauhinia variegata and for this a simple extraction procedure was employed using the sample buffer utilized for SDS-PAGE. After electrophoresis elution of the appropriate protein band $(6 \mathrm{kDa})$ from the gel followed by amino acid sequencing showed the presence of a protein with partial sequence identity to bovine insulin. Only the first five amino acids of each of two chains were sequenced (Table 1). The isolated protein decreased the concentration of blood glucose when injected in both normal and diabetic mice. The protein was found to be associated to chloroplasts when sections of the leaves were examined by immunohistochemical and immunocytochemical microscopy. Latter, chloroplasts were purified and an insulin-like protein was isolated from them and purified by gel filtration and reverse phase chromatography. An ELISA assay showed that the protein cross-reacted with an anti-human insulin antibody (Azevedo, 2003).

Table 2. Amino acid sequences of protein fragments associated to insulins isolated from Canavalia ensiformis, Vigna unguiculata, Bauhinia variegata and Spirulina maxima.

\begin{tabular}{|c|c|c|c|}
\hline $\begin{array}{l}\text { Plant } \\
\text { species }\end{array}$ & $\begin{array}{l}\text { Associated } \\
\text { sequence }\end{array}$ & & Homology \\
\hline \multirow[t]{3}{*}{ C. ensiformis } & Bound peptide fragment & 1 & QNDWLRTKFIR 11 \\
\hline & $\begin{array}{l}\text { Chain A, Crystal Structure of the Ephb2- } \\
\text { Ephrinb2 Complex }\end{array}$ & 51 & QNNWLRTKFIR 61 \\
\hline & Wall-associated kinase 1, A. thaliana & 2 & DWLRTKRIR 10 \\
\hline \multirow[t]{4}{*}{ V. unguiculata } & Bound peptide fragment & 2 & QSPKAFRKYIXTN 12 \\
\hline & $\begin{array}{l}\text { Mouse Tyrosine kinase (Janus kinase 2) } \\
\text { (JAK-2) }\end{array}$ & 428 & 8 SPKDFNKYFLT 438 \\
\hline & Protein phosphatase-2c, A.thaliana & 83 & SPKSERK 89 \\
\hline & Human Serine/Threonine kinase & 285 & ESPSGESKHIQSN 297 \\
\hline \multirow[t]{3}{*}{ B. variegata } & Bound peptide fragment & 1 & DVPDIACAVD 9 \\
\hline & $\begin{array}{l}\text { Glucokinase regulatory protein, } \\
\text { Lactobacillus plantarum }\end{array}$ & 46 & PQ IECAVD 53 \\
\hline & $\begin{array}{l}\text { Glucose inhibited division protein A, } \\
\text { Caulobacter crescentus }\end{array}$ & 233 & DVPQIACGV 241 \\
\hline \multirow[t]{2}{*}{ B. variegata } & Bound peptide fragment & 2 & VSWNGG 7 \\
\hline & $\begin{array}{l}\text { Mannosyl-oligosaccharide alpha-1,2- } \\
\text { mannosidase precursor }\end{array}$ & 260 & VSWNGG 265 \\
\hline \multirow[t]{2}{*}{ S. maxima } & Bound peptide fragment & 1 & HWNWSRCRQV 10 \\
\hline & Glucose transporter, $A$. thaliana & 492 & HWYWSR 497 \\
\hline \multirow[t]{4}{*}{ S. maxima } & Bound peptide fragment & 1 & HWNWSRCHAP 10 \\
\hline & Glucose transporter, A. thaliana & 492 & HWYWSR 497 \\
\hline & $\begin{array}{l}\text { Putative phosphatidylinositol-4-phosphate } \\
\text { 5-kinase, A. thaliana }\end{array}$ & 130 & HWLWGRKH 137 \\
\hline & $\begin{array}{l}\text { Putative monosaccharide transporter } 3 \text {, } \\
\text { Oryza sativa }\end{array}$ & 490 & HWYWSR 495 \\
\hline \multirow[t]{2}{*}{ S. maxima } & Bound peptide fragment & $1 \mathrm{MI}$ & KVPMVLAPPLPVAV-RSPET 20 \\
\hline & Proinsulin Cavia porcellus & $1 \mathrm{M}$ & ALWMHLLTVLALAL-WGPNT 20 \\
\hline
\end{tabular}


As a logical consequence of having detected a protein molecule with immunochemical properties and sequence (partial) similar to bovine insulin in the leaves of a plant we decided to investigate its presence in the leaves of other plants, irrespective of their utilization as anti-hyperglycemic remedies. Furthermore, due to the supposedly new finding of the presence of insulin in chloroplasts we decided to include in our study a member of the Cyanobacteria from which are believed to have originated green plant chloroplasts in an endosymbiontic event about 1 billion years ago (McFadden, 1999). Leaves or aerial parts of species of Rodophyta (red alga), Bryophyta (mosses), Psilophyta (whisk ferns), Lycophyta (club mosses), Sphenophyta (horsetails), gymnosperms, and angiosperms, including monocots and dicots were studied. The cyanobacterium included was Spirulina maxima widely cultivated for food and dietary supplements (Kay, 1991). We detected insulin-like antigens in a multiplicity of species utilizing a modified ELISA plate assay and Western blotting. The two most interesting findings reported in this study were the detection of insulin-like antigens in S. maxima and in Arabidopsis thaliana leaves (Silva et al., 2002). In a related investigation we isolated from $S$. maxima a protein by acidic ethanol extraction that showed a similar behavior in reverse phase chromatography, as does bovine insulin. The $\mathrm{N}$-terminal amino acid sequence of this protein was determined and shown to have homology with sequences of proinsulins (results not published, see Table 2).

We know that up to now no gene sequence was found for insulin in the genome of Arabidopsis (Anon, 2000) or in any other plant genome already published. We do not have any explanation for the conflicting results and the others already referred to above. As for the presence of insulin-like antigens in prokaryotes we register the isolation and characterization of insulin from Escherichia coli (LeRoith et al., 1981).

During the course of these investigations we isolated proteins with molecular weights, chromatographic behaviour, and immunological properties, similar to those of animal insulins. Automated amino acid sequence (Edman) analyses of two of these were shown to be equal to bovine insulin. These analyses also showed minor sequences accompanying the main one(s) (Oliveira et al., 1999a). In some cases, even if we did not have a sequence for an insulin-like protein (probably due to low levels of insulin) in the analysis of our preparations with the above characteristics (proteins with molecular weights, chromatographic behaviour, and immunological properties, similar to those of animal insulins) we detected sequences associated with the preparations. These were possibly originated from protein fragments resulting from limited proteolysis and strongly associated with the purified proteins since they were not eliminated during the several steps necessary for purification, i.e., they co-purify with insulin. These steps included gel filtration, ion exchange and reverse phase chromatography and SDS-PAGE. It is well accepted that protein-protein interaction is an indication of functional partnership and so proteins that associate with insulin could be functionally related to pathways dependent on it (Witke et al., 1998; Pandey and Mann, 2000). We suggest that the fragments associated to insulin whose sequences are shown in Table 2 are fragments of protein components closely associated to the hormone possibly being part of multicomponent complex(es) (Imamura et al., 1999; Yoshida et al., 2000; Pawson and Nash, 2003; Vandenbroere et al., 2003).

Taken together the results obtained by us and summarized above suggest that plants express the protein insulin and that it can be extracted, purified and sequenced. The results also permit us to speculate that insulin in plants exert actions similar to some of those that it performs in animals and may have its action blocked by inhibitors of its pathways in vertebrates.

\section{The presence of insulin in plants: fact or fiction?}

The completion of the sequence of the Arabidopsis thaliana genome and publication of the majority of sequences of the rice genome has brought the hope that a proper gene would be found for insulin in these plants. This did not happen and in fact has strengthened the belief that plants do not contain this information in their genomes (Anon, 2000).

In spite of this disbelief, a number of reviews have recently appeared presenting a body of circumstantial evidence that suggests that the presence of insulin in plants will be recognized. In a recent review Assaad (2001) comments that receptor and signaling molecules like notch, wnt, insulin and TGF-b that are implicated in development and homeostasis in humans are not found in the Arabidopsis genome. The author also says that small "founder" peptides like systemin (18-amino acid peptide originated from a 200amino acid precursor), CLV3 (79-amino acid peptide), phytosulfokines (4- and 5-amino acid peptides) and ENOD40 (13- to 24-amino acid peptide), which are implicated in cellcell signaling in plants, have been missed during annotation of the"Arabidopsis genome. He goes on and says, "Small peptides play important roles in intercellular and whole-plant 
signaling. In this context, it is interesting to note that the Arabidopsis genome encodes an unprecedented number of peptide transporters. Undoubtedly, a large number of plant signal peptides have yet to be uncovered".

In another recent review, this time by Ryan et al. (2002), credit is given for the work done in our laboratory. They comment on several polypeptides that have been suggested as hormone-like signaling molecules in plants. Commenting on leginsulin (Watanabe et al., 1994) they suggest "the inclusion of this polypeptide in the insulin family is premature until an insulin-like role in plants is associated with (it)..." As for the Jack bean seed coat insulin, they state correctly that no biological activity has been associated to it, nor has an insulin gene been reported from plants (Oliveira et al., 1999a).

In yet another review Jonak and Hirt (2002) comment that although plant glycogen synthase kinase lacks a necessary phosphorylation in the N-terminal Ser, which is phosphorylated in PKB (protein kinase B) of the phosphatidylinositol 3-kinase (PI3K)/protein kinase B (PKB) pathway, "some components of the insulin signaling pathway are conserved in plants". No references for the work in which the findings are given.

Short of finding a genetic sequence, which has been and is being actively sought, we may make an exercise on retrieving information by examining the current literature as to the presence of proteins and enzymes related to insulin pathways which have been found in plants. A great number of reports exists in the literature that suggest the existence of proteins with functions, localization, sequences of the corresponding gene or protein, that are similar to proteins which are members of the insulin pathways characteristic of vertebrates. In fact, in a recent "Insight" article in Plant Cell, on auxin transport regulation, Muday (2002) states that "many of the components of the mammalian GLUT4 signal transduction and vesicle secretion mechanism have orthologs in Arabidopsis, a number of which have been implicated directly or indirectly in the regulation of auxin transport...". We list some of these proteins (Table 3 ) and additionally try to give some idea as to the roles their animal counterparts perform in the insulin signaling pathways.

\section{- Insulin receptor (tyrosine kinase)}

The insulin receptor is a member of the family of ligandactivated receptor tyrosine kinases (RTK) that includes receptors for many growth factors. The insulin receptor is a transmembrane protein, which dimerizes even in the absence of the ligand. Tyrosine kinase activity resides in the intracellular portion of the receptor and is autophosphorylated upon ligand binding (Nystrom and Quon, 1999). Until recently receptor kinases of plants (RLK) were believed to be of the serine-threonine kinase family (Becraft, 1998). Nevertheless, Carpi et al. (2002) utilizing a bioinformatics approach published evidence, which was confirmed by immunological analysis, showing that ca. $3.5 \%$ of the protein kinase complement of $A$. thaliana is formed by Tyr-phosphorylating enzymes.

Table 3. List of proteins which are found both in vertebrates and plants and that are associated to insulin signaling pathways.

\begin{tabular}{|c|c|c|c|}
\hline Proteins & Animals & Plants & References \\
\hline Insulin & + & + & Oliveira et al., 1999a \\
\hline $\begin{array}{l}\text { Insulin receptor } \\
\text { (tyrosine kinase) }\end{array}$ & + & + & Carpi et al., 2002 \\
\hline $\begin{array}{l}\text { Insulin receptor substrates, } \\
\text { proteins IRS-1 and IRS-2 }\end{array}$ & + & + & Dietrich et al., 1997 \\
\hline $\begin{array}{l}\text { Glucose transporter } \\
\text { Ibberson et al., } 2000\end{array}$ & + & + & Chiou et al., 1996; \\
\hline $\begin{array}{l}\text { Phosphatidylinositol 3-kinase } \\
\text { (PI 3-kinase) }\end{array}$ & & & $\begin{array}{l}\text { Hong et al., 1994; } \\
\text { Bovet et al., } 2001\end{array}$ \\
\hline Hexokinase & + & + & Moore et al., 2003 \\
\hline MAPK pathway & + & + & Agrawal et al., 2003 \\
\hline TOR (target of rapamycin) & + & + & Menand et al., 2002 \\
\hline Ribosomal S6 Kinase & + & + & Flores et al., 2001 \\
\hline
\end{tabular}

\section{- Insulin receptor substrates proteins IRS-1 and IRS-2}

There are a number of molecule substrates for the insulin receptor tyrosine kinase that provide an interface between the insulin receptor and downstream signaling molecules such as insulin receptor substrate-1 (IRS-1), IRS-2, IRS-3, IRS-4, Shc, and GAB-1. No plant IRS seems to have been found although a zinc finger protein encoded by an Arabidopsis LSD1 gene shows high sequence homology in its carboxyterminal with mammalian IRS-1 (Dietrich et al., 1997).

\section{- Glucose transporter}

Glucose uptake and metabolization is the most well known of the functions in which insulin is involved in metazoans. The glucose transporter GLUT4 is expressed at high levels in muscle and adipocytes and is redistributed from intracellular pools to the cell surface after being phosphorylated by phosphoinositol-3 kinase (Nystrom and Quon, 1999). Plants express a number of monosaccharide 
(hexose/glucose) transporters (Williams et al., 2000) and one of these, which were cloned from sugar beet (Chiou and Bush, 1996) guards a high sequence homology (36\%) with a mammalian glucose transporter (Ibberson et al., 2000).

\section{- Phosphatidylinositol 3-kinase (PI 3-kinase)}

Activation of phosphatidyinositol-3-kinase (PI3K) is a necessary step in the insulin stimulation of glucose transport and is part of the phosphoinositide pathway, one of the best conserved signaling pathways downstream from the insulin receptor substrates (Nystrom and Quon, 1999). Hong and Verma (1994) have cloned a PI3K cDNA from soybean that shows significant sequence homology to mammalian PI3K and is induced during nodule organogenesis. Recently Bovet et al. (2001) showed the presence of PI3- and PI4-kinases in the outer envelope membrane of spinach chloroplasts.

\section{- Hexokinase}

Hexokinase D (glucokinase) is the enzyme that phosphorylates (in the liver) glucose that becomes entrapped within the cell and is then subjected to further metabolism (Brady et al., 1999). Plant hexokinase besides is also involved in sugar sensing processes that are regulated by glucose (Moore et al., 2003).

\section{- MAPK pathway}

This pathway is evolutionarily conserved from unicellular to eukaryote organisms, and is one of the major signaling pathways involved in regulating many cellular activities. It is also associated with insulin signaling in the promotion of cellular growth (Agrawal et al., 2003).

\section{- TOR}

TOR (target of rapamycin) protein is a potential component of the phosphoinositide 3-kinase (PI3K) pathway in Drosophila and was also found in yeast (Oldham and Hafen, 2003) and Arabidopsis (Menand et al., 2002).

\section{- Ribosomal S6 Kinase}

The ribosomal protein S6 kinase (S6K) signaling pathway is involved in the regulation of cell growth and proliferation and is activated by the phosphoinositidedependent protein kinase (PDK1) (Thomas (2002). In maize, phosphorylation of $\mathrm{S} 6$ ribosomal protein on the $40 \mathrm{~S}$ ribosomal subunit is enhanced by IGF (ZmIGF) (Flores et al., 2001).

\section{CONCLUDING REMARKS}

Although we are convinced of the presence of insulin in plants it seems our results will not be accepted until a proper gene for the protein is found in the species we have studied or in plants in general. The additional difficulty of explaining the total sequence identity of the protein we isolated from $C$. ensiformis (and other leguminous plants) with bovine insulin adds to this. However, phylogenetic analysis of vertebrate insulins utilizing amino acid sequences has shown that insulins are poor molecular clocks due to the very high rate of mutation that is observed (Bajaj et al., 1984). It is said that in addition to the six invariant cysteine residues, only ten amino acid residues in the molecule have been fully conserved during evolution of vertebrates (Conlon, 2001). Although these analysis do not touch upon our own sequence analyses it seems reasonable to think that excluding an insulin sequence from plants because of the "impossibility" of it being equal to vertebrate insulins is not correct.

The idea that insulin is a molecule that plays very fundamental and diverse roles in the cell, allied to the fact that it is being found in so many different tissues and organisms, suggests that a "plant insulin" is a strong possibility.

Acknowledgements: The authors wish to thank Conselho Nacional de Desenvolvimento Científico e Tecnológico, CAPES and FAPERJ for financial support.

\section{REFERENCES}

Abel JJ (1926) Crystalline insulin. Proc. Natl. Acad. Sci. USA 12:132-135.

Agrawal GK, Iwahashi H, Rakwal R (2003) Rice MAPKs. Biochem. Biophys. Research. Commun. 302:171-180.

Ajabnoor MA, Tilmisany AK (1988) Effect of Trigonella foenumgraecum on blood glucose levels in normal and alloxan-diabetic mice. J. Ethnopharmacol. 22:45-49.

Anon (2000) Analysis of the genome sequence of the flowering plant Arabidopsis thaliana. Nature 408:796815.

Assaad FF (2001) Of weeds and men: what genomes teach us about plant cell biology. Curr. Opin. Plant Biol. 4:478487.

Azevedo CR (2003) Caracterização parcial de insulina de folhas de Bauhinia variegata. MSc Thesis, UENF.

Bailey CJ, Day C. (1989) Traditional plant medicines as treatments for diabetes. Diabetes Care 12:553-564. 
Bajaj M, Blundell T, Wood S (1984) Evolution in the insulin family - Molecular clocks that tell the wrong time. Biochem. Soc. Symp. 49:45-54.

Banting FG, Best CH, Collip JB, Campbell WR, Fletcher AA (1922) Pancreatic extracts in the treatment of diabetes mellitus. Preliminary report. Can. Med. Assoc. J. 12:141-146.

Barbasov SF, Egorov T, Kochkina VM (1991) Isolation and characterization of soybean insulin-binding proteins. Bioorg. Chem. 17:421-423.

Becraft PW (1998) Receptor kinases in plant development. Trends Plant Sci. 3:384-388.

Best CH (1924) Recent work on insulin. Endocrynology 8:617-629.

Best CH, Scott MA (1923) Possible sources of insulin. J. Metabol. Res. 3:177-179.

Best CH, Smith RG, Scott DA (1924) An insulin-like material in various tissues of the normal and diabetic animal. Amer. J. Physiol. 68:161-182.

Bovet L, Muller MO, Siegenthaler PA (2001) Three distinct lipid kinase activities are present in spinach chloroplast envelope membranes: Phosphatidylinositol phosphorylation is sensitive to wortmannin and not dependent on chloroplast ATP Biochem. Biophys. Res. Commun. 289:269-275.

Brady MJ, Pessin JE, Saltiel AR (1999) Spatial compartmentalization in the regulation of glucose metabolism by insulin. Trends Endocrinol. Metabol. 10:408-413.

Carpi A, Di Maira G, Vedovato M, Rossi V, Naccari T, Floriduz M, Terzi M, Filippini F (2002) Comparative proteome bioinformatics: Identification of a whole complement of putative protein tyrosine kinases in the model flowering plant Arabidopsis thaliana. Proteomics 2:1494-503.

Chiou TJ, Bush DR (1996) Molecular cloning, immunochemical localization to the vacuole, and expression in transgenic yeast and tobacco of a putative sugar transporter from sugar beet. Plant Physiol. 110:511-520.

Collier E, Watkinson A, Cleland CF, Roth J (1987) Partial purification and characterization of an insulin-like material from spinach and Lemna gibba G3. J. Biol. Chem. 262:6238-6247.

Collip JB (1923) Glucokinin. A new hormone present in plant tissue. Preliminary paper. J. Biol. Chem. 56:513-543.

Conlon JM (2001) Evolution of the insulin molecule: insights into structure-activity and phylogenetic relationships. Peptides 22:1183-1193.

da Silva KL, Cechinel V (2002) Plants of the genus Bauhinia: Chemical composition and pharmacological potential. Quimica Nova 25:449-454.
Dietrich RA, Richberg MH, Schmidt R, Dean C, Dangl JL (1997) A novel zinc finger protein is encoded by the Arabidopsis LSD1 gene and functions as a negative regulator of plant cell death. Cell 88:685-694.

Dinkova TD, Aguilar R, Sánchez de Jimenez E (2000) Expression of maize eukaryotic initiation factor (eIF) iso4E is regulated at the translational level. Biochem. J. 351:825-831.

du Vigneaud V, Jensen H, Wintersteiner O (1928) Studies on crystalline insulin. III. Further observations on the crystallization of insulin and on the nature of the sulfur linkage. The isolation of cysteine and tyrosine from hydrolyzed crystalline insulin. J. Pharmacol. Exp. Ther. 32: 367-385.

Ellis MM, Eyster WH (1923) Some effects of insulin and glucokinin on maize seedlings. Science 58:541-542.

Eng J, Yalow RS (1981) Evidence against extra pancreatic insulin synthesis. Proc. Natl. Acad. Sci. USA 78:45764578.

Ernst E (1997) Plants with hypoglycemic activity in humans. Phytomedicine 4:73-78.

Eyster WH, Ellis MM (1924) Growth of maize seedlings as affected by glucokinin and insulin. J. Gen. Physiol. 6:653670.

Fernandes KVS, Sabelli PA, Barratt DHP, Richardson M, Xavier-Filho J, Shewry PR (1993) The resistance of cowpea seeds to bruchid beetles is not related to levels of cysteine proteinase - inhibitors. Plant Mol. Biol. 23:215-219.

Flores CG, Aguilar R, De la Cruz HR, Albores M, de Jimenez ES (2001) A maize insulin-like growth factor signals to a transduction pathway that regulates protein synthesis in maize. Biochem. J. 358:95-100.

Goodman DBP, Davis WL (1993) Insulin accelerates the postgerminative development of several fat-storing seeds. Biochem. Biophys. Res. Commun. 190:440-446.

Grover JK, Vats V, Yadav S (2002) Effect of feeding aqueous extract of Pterocarpus marsupium on glycogen content of tissues and the key enzymes of carbohydrate metabolism. Mol. Cel. Biochem. 241:53-59.

Hong, Z, Verma DPS (1994) A PtdIns 3-kinase is induced during soybean nodule organogenesis and is associated with membrane proliferation. Proc. Natl. Acad. Sci. USA 91:9617-9621.

Ibberson M, Uldry M, Thorens B (2000) GLUTX1, a novel mammalian glucose transporter expressed in the central nervous system and insulin-sensitive tissues. J. Biol. Chem. 275:4607-4612.

Ilgoutz SC, Knittel N, Lin JM, Sterle S, Gayler KR (1997) Transcription of genes for conglutin gamma and a leginsulin-like protein in narrow-leafed lupin. Plant Mol. Biol. 34:613-627. 
Imamura T, Vollenweider P, Egawa K, Clodi M, Ishibashi K, Nakashima N, Ugi S, Adams JW, Brown JH, Olefsky JM. (1999) G alpha-q/11 protein plays a key role in insulininduced glucose transport in 3T3-L1 adipocytes. Mol. Cell Biol. 19:6765-6774.

Jonak C, Hirt H (2002) Glycogen synthase kinase 3/ SHAGGY-like kinases in plants: an emerging family with novel functions. Trends Plant Sci. 7:457-461.

Juliane C (1929) Ação hipoglicemiante da unha-de-vaca. Rev. Med. Pharm. Chim. Phys. 2:165-169.

Kay RA (1991) Microalgae as food and supplement. Crit. Rev. Food Sci. Nutrit. 30:555-573.

Khanna P, Jain SC, Panagariya A, Dixit VP (1981) Hypoglycemic activity of Polypeptide-P from a plant source. J. Nat. Prod. 44:648-655.

Khanna P, Nag TN, Chandrajaia S, Mohan SV (1976) Process for isolation of insulin from plant source. United States Patent 3:945-988.

Khanna P, Nag TN, Jain SC, Mohan S (1974) Extraction of insulin from a plant source. 3rd International Congress on Plant Tissue \& Cell Cultures, 21-26th July, Leicester, UK.

Komatsu S, Hirano H (1991) Plant basic 7S globulin-like proteins have insulin and insulin-like growth factor binding activity. FEBS Lett. 294:210-212.

Korczowski MM (1985) Dietary control of diabetes: reality or myth? South Med. J. 78:979-986.

Kuhn TS (1970) The Structure of Scientific Revolutions, The University of Chicago Press, Chicago.

Laskowski M, Haessler HA, Miech RP, Peanasky RJ, Laskowski M (1958) Effect of trypsin inhibitor on passage of insulin across the intestinal barrier. Science 127:1115-1116.

LeRoith D, Shiloach J, Heffron R, Rubinovitz C, Tanenbaum R, Roth J (1985) Insulin-related material in microbes: similarities and differences from mammalian insulins. Can. J. Biochem. Cell Biol. 63:839-849.

LeRoith D, Shiloach J, Roth J \& Lesniak MA (1980) Evolutionary origins of vertebrate hormones: Substances similar to mammalian insulins are native to unicellular eukaryotes. Proc. Natl. Acad. Sci. USA 77:6184-6188.

LeRoith D, Shiloach J, Roth J, Lesniak MA (1981) Insulin or a closely related molecule is native to Escherichia coli. J. Biol. Chem. 256:6533-6536.

Luo J, Fort DM, Carlson TJ, Noamesi BK, nii-Amon-Kotei D, King SR, Tsai J, Quan J, Hobensack C, Lapresca P, Waldeck N, Mendez CD, Jolad SD, Bierer DE, Reaven GM (1998) Cryptolepis sanguinolenta: an ethnobotanical approach to drug discovery and the isolation of a potentially useful new antihyperglycaemic agent. Diab. Medicine 15:367-374.
Macedo MLR, Andrade LBS, Moraes RA, Xavier-Filho J (1993) Vicilin variants and the resistance of cowpea (Vigna unguiculata) seeds to the cowpea weevil (Callosobruchus maculatus). Comp. Biochem. Physiol. 105C:89-94.

Macleod JJR (1924) Insulin. Physiol. Rev. 4:21-67.

McFadden GI (1999) Endosymbiosis and evolution of the plant cell Curr. Opin. Plant Biol. 2:513-519.

Menand B, Desnos T, Nussaume L, Berger F, Bouchez D, Meyer C, Robaglia C. (2002) Expression and disruption of the Arabidopsis TOR (target of rapamycin) gene. Proc. Natl. Acad. Sci. USA 99:6422-6427.

Moore B, Zhou L, Rolland F, Hall Q, Cheng WH, Liu YX, Hwang I, Jones T, Sheen J (2003) Role of the Arabidopsis glucose sensor HXK1 in nutrient, light, and hormonal signaling. Science 300:332-336.

Muday GK (2002) An emerging model of auxin transport regulation. Plant Cell 14:293-299.

Muthukumar G, Lenard J (1991) A preproinsulin-like pseudogene from Neurospora crassa. Mol. Cel. Endocrinol. 82:275-283.

$\mathrm{Ng}$ TB, Wong CM, Li WW, Yeung HW (1986) Insulin-like molecules in Momordica charantia seeds. J. Ethnopharmacol. 15:107-117.

Nystrom FH, Quon MJ (1999) Insulin signaling: metabolic pathways and mechanisms for specificity. Cell Signal 11:563-574.

Oldham S, Hafen E (2003) Insulin/IGF and target of rapamycin signalling: a TOR de force in growth control. Trends Cell Biol. 13:79-85.

Oliveira AEA, Machado OLT, Gomes VM, Xavier-Neto J, Pereira AC, Vieira JGH, Fernandes KVS, Xavier-Filho J (1999a) Jack bean seed coat contains a protein with complete sequence homology to bovine insulin. Protein Pept. Lett. 6:15-21.

Oliveira AEA, Sales MP, Machado OLT, Fernandes KVS, Xavier-Filho J (1999b) The toxicity of Jack bean (Canavalia ensiformis) cotyledon and seed coat proteins to the cowpea weevil (Callosobruchus maculatus). Entomol. Exp. Appl. 92:249-255.

Oliveira AEA, Sassaki GL, Iacomini M, da Cunha M, Gomes VM, Fernandes KVS, Xavier-Filho J (2001) Isolation and characterization of a galactorhamnan polysaccharide from the seed coat of Canavalia ensiformis that is toxic to the cowpea weevil (Callosobruchusmaculatus). Entomol. Exp. Appl.101: 225-231.

Pandey A, Mann M (2000) Proteomics to study genes and genomes. Nature 405:837-846.

Pawson T, Nash P (2003) Assembly of cell regulatory systems through protein interaction domains. Science 300:445-452.

Pepato MT, Keller EH, Baviera AM, Kettelhut IC, Vendramini RC, Brunetti IL (2002) Anti-diabetic activity of Bauhinia forficata decoction in streptozotocin-diabetic rats. J. Ethnopharmacol. 81:191-197. 
Rolland F, Winderickx J, Thevelein JM (2001) Glucosesensing mechanisms in eukaryotic cells. Trends Biochem. Sci. 26:310-317.

Ryan CA, Pearce G, Scheer J, Moura DS (2002) Polypeptide hormones. Plant Cell 14:S251-S264.

Sales MP, Gerhardt IR, Grossi-de-Sa MF, Xavier-Filho J (2000) Do legume storage proteins play a role in defending seeds against bruchids? Plant Physiol. 124:515-522.

Sánchez de Jiménez, E, Beltrán-Penã E, Ortíz-López A (1999) Insulin-stimulated ribosomal protein synthesis in maize embryonic axis during germination. Physiol. Plant. 105:148-154.

Santos VO (2003) Presença de insulina em Phaseolus vulgaris L. cv. Carioca. Monograph, Universidade Estadual Norte Fluminense, Campos dos Goytacazes, RJ.

Schechter R, Holtzclaw L, Sadiq F, Kahn A, Devaskar S. (1988) Insulin synthesis by isolated rabbit neurons. Endocrinol. 123:505-513.

Silva LB, Santos SSS, Azevedo CR, Cruz MAL, Venâncio TM, Cavalcante CP, Uchoa AF, Astolfi S, Oliveira AEA, Fernandes KVS, Xavier-Filho J (2002) The leaves of green plants as well as a cyanobacterium, a red alga, and fungi contain insulin-like antigens. Brazil. J. Med. Biol. Res. 35:297-303.

Smit AB, Van Kesteren RE, Li KW, Van Minnen J, Spijker S, Van Heerikhuizen H, Geraerts WPM (1998) Towards understanding the role of insulin in the brain: Lessons from insulin-related signalling systems in the invertebrate brain. Progr. Neurobiol. 54:35-54.

Thomas G (2002) The S6 kinase signaling pathway in the control of development and growth. Biol. Res. 35:305313.

Vandenbroere I, Paternotte N, Dumont JE, Erneux C, Pirson I (2003) The c-Cbl-associated protein and c-Cbl are two new partners of the $\mathrm{SH} 2$-containing inositol polyphosphate 5-phosphatase SHIP2. Biochem. Biophys. Res. Commun. 300:494-500.

Venâncio TM (2001) Presença de insulina em feijão-de-corda [Vigna unguiculata (L.) Walp.]. Monograph, Universidade Estadual Norte Fluminense, Campos dos Goytacazes, RJ.

Venâncio TM, Oliveira AEA, Silva LB, Machado OLT, Fernandes KVS, Xavier-Filho J (2003) A protein with sequence homology to bovine insulin is found in the legume Vigna unguiculata (cowpea). Braz. J. Med. Biol. Res., in press.

Watanabe Y, Barbashov SF, Komatsu S, Hemmings AM, Miyagi M, Tsunasawa S, Hirano H (1994) A peptide that stimulates phosphorylation of the plant insulin-binding protein - Isolation, primary structure and cDNA cloning. Eur. J. Biochem. 224:167-172.

Williams LE, Lemoine R, Sauer N (2000) Sugar transporters in higher plants - A diversity of roles and complex regulation. Trends Plant Sci. 5:283-290.

Wintersteiner O, du Vigneaud V, Jensen H (1928) Studies on crystalline insulin. V. The distribution of nitrogen in crystalline insulin. J. Pharmacol. Exp. Ther. 32:397-411.

Witke W, Podtelejnikov AV, Di Nardo A, Sutherland JD, Gurniak CB, Dotti C, Mann M (1998) In mouse brain profilin I and profilin II associate with regulators of the endocytic pathway and actin assembly EMBO J. 17:967-976.

Xavier-Filho J, Sales MP, Fernandes KVS, Gomes VM (1996) The resistance of cowpea (Vigna unguiculata) seeds to the cowpea weevil (Callosobruchus maculatus) is due to the association of variant vicilins (7S storage proteins) to chitinous structures in the insect's midgut. Arq. Biol. Tecnol. 39:693-699.

Yamazaki T, Takaoka M, Katoh E, Hanada K, Sakita M, Sakata K, Nishiuchi Y, Hirano H (2003) A possible physiological function and the tertiary structure of a 4$\mathrm{kDa}$ peptide in legumes. Eur. J. Biochem. 270:1269-1276.

Yoshida T, Sato M, Ozawa T, Umezawa Y (2000) An SPRbased screening method for agonist selectivity for insulin signalling pathways based on the binding of phosphotyrosine to its specific binding protein. Anal. Chem. 72:6-11.

Yoshikawa M, Murakami T, Shimada H, Matsuda H, Yamahara J, Tanabe G, Muraoka O (1997) Salacinol, potent antidiabetic principle with unique thiosugar sulfonium sulfate structure from the ayurvedic traditional medicine Salacia reticulata in Sri Lanka and India. Tetrahedron Lett. 38:8367-8370.

Zick, Y (2001) Insulin resistance: a phosphorylation-based uncoupling of insulin signalling. Trends Cell Biol. $11: 437-441$. 